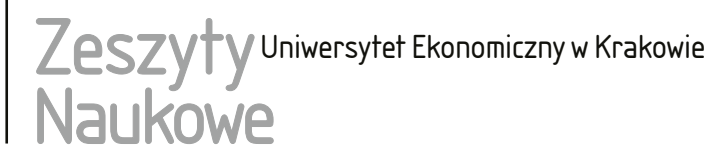

\title{
Konkurencyjność polskiego eksportu artykułów przemysłowych do krajów Grupy Wyszehradzkiej a spójność ekonomiczna ugrupowania*
}

\section{Streszczenie}

Celem artykułu jest ukazanie konkurencyjności polskiego eksportu produktów przemysłowych do krajów Grupy Wyszehradzkiej. W analizie konkurencyjności wykorzystano wskaźniki RCA, IIT oraz udziały w eksporcie. Zagadnienie to nabiera znaczenia zwłaszcza w kontekście możliwości rozszerzenia wymiany. Badania prowadzono, aby zwrócić uwagę na możliwości wykorzystania istniejącej spójności ekonomicznej badanych gospodarek w tej dziedzinie. Wnioski z badań potwierdzają istnienie takich możliwości, lecz konieczna jest likwidacja barier infrastrukturalnych oraz stworzenie płaszczyzny wymiany doświadczeń związanych z poprawą konkurencyjności. Mogłoby to przynieść znaczący wzrost konkurencyjności, gdyż wszyscy członkowie Grupy mieli podobne warunki początkowe, natomiast różne drogi rozwoju doprowadziły do nieco innych wyników gospodarczych.

Ewa Szymanik, Uniwersytet Ekonomiczny w Krakowie, Wydział Ekonomii i Stosunków Międzynarodowych, Katedra Mikroekonomii, ul. Rakowicka 27, 31-510 Kraków, e-mail: szymanie@uek. krakow.pl

* Artykuł powstał w wyniku realizacji projektu badawczego 063/WE-KMi/01/2016/S/6063, finansowanego ze środków przyznanych Wydziałowi Ekonomii i Stosunków Międzynarodowych Uniwersytetu Ekonomicznego w Krakowie w ramach dotacji na utrzymanie potencjału badawczego. 
Słowa kluczowe: Grupa Wyszehradzka, konkurencyjność eksportu, spójność gospodarek, Unia Europejska.

Klasyfikacja JEL: F18, F43, O52.

\section{Wprowadzenie}

W Polsce od końca lat 80. XX w. wzrastało zainteresowanie ekonomią i polityką krajów Europy Zachodniej, zwłaszcza państw ówczesnych Wspólnot Europejskich. Zmiany polityczne rozpoczęte w 1989 r. pogłębiły ten proces. Rozpad RWPG stanowił naturalny punkt wyjścia do zmiany ukierunkowania handlu i zapoczątkował dążenia byłych jej członków do wejścia w zachodnie struktury, jednak państwa EWG nie były zainteresowane rozszerzeniem Wspólnot, proponując w zamian pogłębienie współpracy między krajami Europy Środkowej, co miało stanowić rodzaj ,poligonu doświadczalnego” przed podjęciem ewentualnych dalszych kroków stowarzyszeniowych. Te propozycje stanowiły punkt wyjścia do powstania najpierw Trójkąta, a później Czworokąta Wyszehradzkiego.

Początkowo współpraca ta nie miała ożywionego charakteru, jednakże stopniowo zaczęła się rozwijać, czemu sprzyjało sąsiedztwo oraz wiele podobieństw gospodarczych. W każdym z tych krajów miały miejsce procesy przemian gospodarczo-politycznych, każdy był zainteresowany rozwojem handlu z krajami Unii. Ponieważ jednak w okresie przedakcesyjnym istniało wiele ograniczeń, rozwój wymiany wewnątrz Grupy Wyszehradzkiej okazał się procesem naturalnym, choć na początku powolnym. Do ożywienia doszło dopiero po akcesji w struktury unijne. Przyczyniła się do tego również realizacja zasad polityki spójności Unii.

Celem tej polityki jest przyspieszanie i pogłębianie procesów konwergencji realnej pomiędzy regionami, a o jej potrzebie świadczy utrzymujące się zróżnicowanie poziomu gospodarczego między poszczególnymi krajami UE. Zwiększenie spójności społeczno-ekonomicznej odbywa się przez wsparcie rozwoju najuboższych regionów Wspólnoty. W tym celu powołano kilka funduszy, w tym Europejski Fundusz Rozwoju Regionalnego (1973 r.), którego zadaniem było wspieranie obszarów słabiej rozwiniętych, szczególnie przemysłowych. Fundusz ten pełni główną rolę w realizowanej obecnie polityce spójności Unii. Kolejne modyfikacje, w tym przyjęcie strategii Europa 2020, nie spowodowały zasadniczych zmian w kwestii jednego z priorytetów - rozwoju gospodarczego i poprawy konkurencyjności całego ugrupowania, a co się z tym wiąże - także poszczególnych krajów i ich grup [Ocena... 2011, s. 8-11].

Celem artykułu jest ukazanie konkurencyjności polskiego eksportu artykułów przemysłowych do krajów Grupy Wyszehradzkiej na tle wymiany wewnątrz całego ugrupowania poprzez analizę odpowiednich wskaźników i zarysowanie 
możliwości rozszerzenia wymiany w kontekście spójności ekonomicznej badanych gospodarek.

\section{Konkurencyjność w polityce spójności Unii Europejskiej}

Podstawy prawne zasad polityki spójności określają: Traktat o Unii Europejskiej i Traktat o funkcjonowaniu Unii Europejskiej (http://eur-lex.europa. $\mathrm{eu} /$ legal-content/PL/TXT/?uri=uriserv:OJ.C_.2012.326.01.0001.01.POL\&toc= OJ:C:2012:326:FULL\#C_2012326PL.01001301, data dostępu: 19.07.2016). Zasady te są określone bardzo ogólnie. W Traktacie o UE są wymienione cele polityki spójności (art. 3) oraz zapewnienie o wsparciu rozwoju gospodarczego, dążeniu do jego trwałości oraz spójności podejmowanych w tym celu działań (art. 21). W Traktacie o funkcjonowaniu UE spójności gospodarczej w art. 4,7 i 174 stwierdzono, że Unia zmierza do zmniejszenia dysproporcji w rozwoju regionów (174) i do ustanowienia podziału kompetencji w ramach spójności między Unią a państwem członkowskim.

Podobnie ogólne są postanowienia dotyczące reguł konkurencji. W art. 3 przedstawiono działania na rzecz trwałego rozwoju Europy, którego podstawą jest zrównoważony wzrost gospodarczy oraz społeczna gospodarka rynkowa o wysokiej konkurencyjności. Jednak nie określono, w jaki sposób ma ona być osiągana w ramach prowadzonej polityki spójności. Podano tylko ogólne zasady handlu (art. 37) oraz określono reguły konkurencji (art. 101-106) i reguły pomocy państwa (107-109). Obydwa dokumenty pozostawiają więc swobodę wyboru metod kształtowania konkurencyjności w ramach Unii.

Polityka spójności mieści się w kategorii zrównoważonego wzrostu, w dwóch podkategoriach: konkurencyjności oraz polityce spójności i obejmuje wydatki z funduszy strukturalnych na takie cele, jak: konwergencja, konkurencyjność regionalna i zatrudnienie, europejska współpraca terytorialna i pomoc techniczna oraz wydatki z Funduszu Spójności. Warto podkreślić, że w niektórych dziedzinach wsparcie jest udzielane w ramach różnych kategorii budżetowych. Chociaż kategoria pierwsza nosi nazwę „konkurencyjność”, to największa część środków na wsparcie konkurencyjności przedsiębiorstw i regionów jest wydatkowana w związku z realizacją polityki spójności w ramach takich celów, jak: „konkurencyjność regionalna i zatrudnienie” oraz „Konwergencja” [Ocena... 2011, s. 11-12].

W poszczególnych krajach Grupy Wyszehradzkiej budowa konkurencyjności i spójności jest różnie rozumiana. Na Węgrzech głównym celem jest równomierne wsparcie wszystkich celów rozwojowych, Słowacja zdecydowała się na przeznaczenie środków przede wszystkim na wsparcie infrastruktury i rozwój gospodarki opartej na wiedzy, zaś Polska i Czechy postanowiły przyspieszyć rozwój gospo- 
darczy. Nasz kraj jest liderem pod względem udziału środków przeznaczonych na wsparcie przedsiębiorczości, transportu i infrastruktury energetycznej, co potwierdzają wyniki badań przedstawionych w dalszej części artykułu. Czechy inwestowały przede wszystkim w edukację i szkolenia [Ocena... 2011, s. 24-25], co w dłuższym okresie może przynieść większe przyspieszenie rozwoju niż w Polsce i znaczną poprawę konkurencyjności czeskiej gospodarki.

\section{Definicje i mierniki konkurencyjności gospodarki}

Zmiany ekonomiczne i polityczne i wynikająca z nich konieczność adaptacji do reguł światowego handlu postawiły przed Polską nowe wyzwania, m.in. poprawę konkurencyjności. W literaturze przedmiotu konkurencyjność definiowana jest na wiele sposobów (szerzej na ten temat zob. [Szymanik 2016, s. 107-122]) dotychczas nie udało się wypracować uniwersalnej definicji. Trudność wynika z faktu, że pojęcie to oznacza zarówno zdolność do uczestnictwa w walce, jak i ocenę ex post jej wyników, czyli zawiera zarówno element dynamiczny, związany z analizą czynników kształtujących długookresową zdolność do konkurowania, jak i element statyczny, wyrażający się w ocenie tej zdolności w danym momencie. Stąd rozróżnienie pozycji i zdolności konkurencyjnej (utożsamianej często z konkurencyjnością kraju) pojawiające się w literaturze (m.in. [Gorynia i Łaźniewska 2010, s. 58 i 70; Misala 2011, s. 77 i nast.]). Innym problemem jest bardzo szeroki aspekt pojęciowy, sprawiający, że proponowane definicje są albo bardzo ogólne, o małej użyteczności badawczej, albo szczegółowe, ale dotyczące tylko niewielkiego wycinka życia gospodarczego kraju. Ponadto część ekonomistów określa konkurencyjność w zależności od zakresu badania - np. J. Wierzbołowski [1995, s. 20-21] wyróżnia konkurencyjność sensu stricto (inaczej mikrokonkurencyjność) oraz sensu largo (makrokonkurencyjność), a S. Flejterski [1984, s. 9] wyróżnia jeszcze mezokonkurencyjność, to jest eksport towarów danej branży lub gałęzi. Można też badać gospodarkę w rozszerzonym aspekcie, ujmując wiele czynników, np. za pomocą Zintegrowanego Modelu Konkurencyjności Gospodarki [Jagiełło 2008, s. 65-68]. Podejmowano też liczne inne próby [Puślecki i Walkowski 2010; Radło 2008; Daszkiewicz i Olczyk 2008, s. 13-15] (zwłaszcza instytucje międzynarodowe, np. WEF czy Bank Światowy), lecz prawdopodobnie niemożliwe jest pełne ustalenie wszystkich czynników wpływających na konkurencyjność, zwłaszcza że ulegają one zmianom [Szymanik 2017].

Celem pracy jest ukazanie konkurencyjności polskiego eksportu produktów przemysłowych w wymianie z krajami Grupy Wyszehradzkiej na tle wymiany wewnątrz UE, szczególnie podczas kryzysu w latach 2007-2012 i następnych, i na tej podstawie ukazanie spójności badanej grupy, gdyż eksport jest dziedziną, która 
w sposób syntetyczny odzwierciedla zmiany w strukturze gospodarki. Wyboru towarów dokonano ze względu na ich znaczenie dla polskiego handlu zagranicznego. W tym celu przyjęto definicję jednoczynnikową sformułowaną przez D. Hübner [1994, s. 336]: ,,przez międzynarodową konkurencyjność gospodarki krajowej rozumie się jej konkurencyjność cenową i pozacenową, a więc atrakcyjność eksportowanych przez dany kraj towarów i usług oraz produktów będących substytutami dóbr importowanych".

Zakres badań został ograniczony również ze względu na przeprowadzone wcześniej badania potencjału konkurencyjności państw Grupy Wyszehradzkiej, których podjął się T. Brodzicki [2013, s. 85-115]. Jego praca obejmuje lata 1999-2008 i opiera się na analizie podstawowych mierników używanych do pomiaru konkurencyjności handlu, czyli wskaźników RCA i IIT, w formie nieobciążonej. Użycie właśnie tych form jest uzasadnione, gdyż nieobciążony wskaźnik przewagi komparatywnej WCRCA pozwala uniknąć wpływu wrażliwości nierównowagi w wymianie handlowej na wynik pomiaru i daje wartości średnie.

Wskaźnik IIT, opisujący wymianę wewnątrzgałęziową, ukazuje stopień podobieństwa gospodarek i może być traktowany jako miernik spójności ekonomicznej. Został on zdekomponowany ze względu na specyfikę dóbr będących przedmiotem wymiany na dwie części: pionową i poziomą, mające odmienne determinanty.

Analiza IIT jest istotna przy badaniu spójności ekonomicznej, ponieważ największe wartości przyjmuje zwykle wymiana handlowa między gospodarkami podobnymi i dotyczy szczególnie substytutów. Dobrym przykładem jest handel między Polską a Niemcami, gdzie największą część stanowi grupa „maszyny i urządzenia"1, zarówno w imporcie, jak i eksporcie. Potwierdza to analiza innych gospodarek, gdzie im większe jest podobieństwo, a co za tym idzie - spójność, tym wymiana jest bardziej ożywiona i sprzyja dalszemu zacieśnianiu stosunków gospodarczych. Największe wartości przyjmuje handel między krajami o zbliżonym poziomie rozwoju. Zatem im większa jest wartość wskaźnika IIT, tym bardziej spójne ze sobą są poszczególne działy gospodarek oraz same gospodarki. Jednak zwiększenie wartości handlu zależy nie tylko od poprawy konkurencyjności i spójności, ale także od czynników trudno mierzalnych, takich jak np. zmiany polityczne i krótkotrwałe trendy podyktowane bieżącymi potrzebami kraju.

W niniejszym artykule skupiono się na analizie mniej zaawansowanej formy wskaźników: RCA w formie logarytmicznej oraz IIT uzupełnionych o udziały poszczególnych państw badanej grupy w polskim handlu zagranicznym. Choć są nieco mniej dokładne, również one ukazują kierunek zmian konkurencyjności eksportu oraz spójności Grupy i mogą być stosowane jako podstawa ustalania wytycznych rozwoju eksportu.

\footnotetext{
${ }^{1}$ W ramach tej grupy większość w polskim eksporcie stanowią części do maszyn.
} 
Wskaźnik ujawnionej przewagi komparatywnej RCA

$$
R C A_{i}=\ln X_{i}-\ln M_{i},
$$

gdzie:

$X_{i}$ - wartość eksportu grupy towarowej $i$,

$M_{i}$ - wartość importu grupy towarowej $i$.

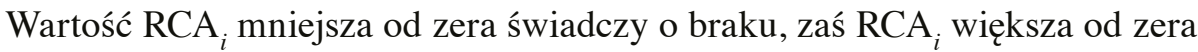
- o występowaniu ujawnionej przewagi względnej oraz o intensywności międzygałęziowego handlu i międzynarodowego podziału pracy.

Wskaźnik handlu wewnątrzgałęziowego IIT

$$
I I T=\left[\frac{\left(X_{i}+M_{i}\right)-\left|X_{i}-M_{i}\right|}{X_{i}+M_{i}}\right] \cdot 100 .
$$

Wartości bliskie $100 \%$ świadczą o wysokiej intensywności wymiany i dużym podobieństwie struktur handlowych, a co za tym idzie - również wysokiej spójności ekonomicznej badanych gospodarek.

Udziały danego towaru w eksporcie

$$
U=\frac{X_{i}}{\sum X_{i}} \cdot 100
$$

gdzie: $X_{i}$ - wartość eksportu towaru $i$.

\section{Wymiana handlowa pomiędzy Polską a krajami Grupy Wyszehradzkiej na tle handlu wewnątrzunijnego}

\subsection{Uwagi ogólne}

Warunki wymiany między Polską a pozostałymi członkami Grupy początkowo określały postanowienia CEFT-y, a później, po wejściu w struktury unijne, panujące tam przepisy. Rozszerzenie UE nie spowodowało istotnych zmian w strukturze geograficznej eksportu analizowanych krajów, gdyż występują tu, oprócz sąsiedztwa, także liczne związki historyczne sprzyjające trwałości kontaktów. Warto przy tym pamiętać, że od czasu akcesji można zauważyć malejące znaczenie sprzedaży towarów do krajów Unii nie tylko w Polsce, ale w całej Grupie. Mimo to Czechy są jednym z ważniejszych partnerów handlowych Polski.

Z tabeli 1 wynika, że badane kraje zawsze były ważnymi partnerami handlowymi. Czechy w 2014 r. zajęły w polskim imporcie wewnątrzunijnym piąte 
Tabela 1. Udziały wybranych krajów w polskim handlu wewnątrzunijnym w latach 2004-2014 (w \%)

\begin{tabular}{|c|c|c|c|c|c|c|c|c|c|c|c|}
\hline Kraj & 2004 & 2005 & 2006 & 2007 & 2008 & 2009 & 2010 & 2011 & 2012 & 2013 & 2014 \\
\hline \multicolumn{12}{|c|}{ Udziały w imporcie } \\
\hline Belgia & 3,72 & 4,12 & 3,98 & 3,9 & 3,8 & 3,8 & 4 & 3,7 & 3,9 & 3,9 & 4,1 \\
\hline Francja & 9,85 & 4,43 & 8,69 & 8 & 7,6 & 7,4 & 7,3 & 7 & 6,8 & 6,5 & 6,3 \\
\hline Hiszpania & 3,91 & 2,81 & 3,12 & 3,3 & 3,5 & 3,6 & 3,4 & 3,3 & 3,6 & 3,7 & 3,4 \\
\hline Holandia & 5,11 & 4,48 & 4,98 & 5,3 & 5,6 & 5,9 & 6,2 & 6,3 & 6,8 & 6,6 & 6,4 \\
\hline Niemcy & 35,75 & 38,68 & 37,99 & 37,5 & 37,1 & 36,2 & 36,8 & 37,4 & 37,1 & 37 & 37,3 \\
\hline Szwecja & 3,96 & 3,55 & 3,49 & 3,4 & 3,3 & 3 & 3,2 & 3,4 & 3,3 & 3,2 & 3,1 \\
\hline Wielka Br & 4,87 & 4,83 & 4,54 & 4,8 & 4,6 & 4,8 & 4,6 & 4,4 & 4,2 & 4,5 & 4,4 \\
\hline Włochy & 11,55 & 11,08 & 10,75 & 10,7 & 10,5 & 11 & 9,6 & 9 & 9,1 & 9,1 & 9,6 \\
\hline Czechy & 5,31 & 5,37 & 5,52 & 5,4 & 5,8 & 5,8 & 6,4 & 6,2 & 6,4 & 6,3 & 6,1 \\
\hline Słowacja & 2,42 & 5,86 & 2,8 & 2,8 & 3,1 & 3,3 & 3,5 & 3,5 & 3,6 & 3,4 & 3,1 \\
\hline Węgry & 2,77 & 2,75 & 3,4 & 3,3 & 2,9 & 3 & 2,9 & 2,9 & 2,8 & 2,8 & 2,7 \\
\hline \multicolumn{12}{|c|}{ Udziały w eksporcie } \\
\hline Belgia & 4,04 & 4,01 & 3,57 & 3,4 & 3,3 & 3 & 3 & 3 & 2,7 & 2,9 & 2,9 \\
\hline Francja & 7,63 & 8,58 & 8,06 & 7,7 & 8 & 8,7 & 8,6 & 7,9 & 7,7 & 7,5 & 7,2 \\
\hline Hiszpania & 3,1 & 3,29 & 3,21 & 3,7 & 3,2 & 3,3 & 3,4 & 3,1 & 2,6 & 3 & 3,2 \\
\hline Holandia & 5,43 & 5,19 & 4,97 & 4,9 & 5,2 & 5,3 & 5,5 & 5,6 & 5,9 & 5,3 & 5,4 \\
\hline Niemcy & 37,94 & 36,82 & 35,06 & 32,8 & 32,2 & 32,8 & 33 & 33,4 & 33,1 & 33,4 & 34 \\
\hline Szwecja & 4,42 & 4,24 & 4,15 & 4,1 & 4,1 & 3,4 & 3,7 & 3,7 & 3,5 & 3,6 & 3,7 \\
\hline Wielka Brytania & 6,84 & 7,36 & 7,38 & 7,5 & 7,4 & 8 & 7,9 & 8,3 & 8,9 & 8,7 & 8,2 \\
\hline Włochy & 7,73 & 8,11 & 8,45 & 8,4 & 7,7 & 8,6 & 7,5 & 6,8 & 6,4 & 5,8 & 5,9 \\
\hline Czechy & 5,47 & 5,79 & 7,16 & 5,4 & 7,3 & 7,3 & 7,6 & 8 & 8,3 & 8,3 & 8,3 \\
\hline Słowacja & 2,26 & 2,41 & 2,7 & 2,8 & 3,2 & 2,9 & 3,4 & 3,1 & 3,4 & 3,5 & 3,3 \\
\hline Węgry & 3,25 & 3,58 & 3,93 & 3,7 & 3,6 & 3,4 & 3,6 & 3,3 & 3,2 & 3,4 & 3,4 \\
\hline
\end{tabular}

Źródło: obliczenia własne na podstawie danych z: [Rocznik statystyczny... 2005-2015].

miejsce, Węgry - dwunaste, zaś Słowacja - siódme ex aequo ze Szwecją, natomiast w eksporcie były to odpowiednio miejsca drugie, ósme i dziewiąte. Udział Czech w wymianie stale rośnie pomimo kolejnych rozszerzeń UE, pozostałych zaś utrzymuje się cały czas na podobnym poziomie. Świadczy to o silnych i stabilnych powiązaniach handlowych, na które kryzys nie miał większego wpływu. Takie powiązania występują między krajami o podobnych strukturach gospodarczych. Wielkość wymiany towarów przemysłowych w tym okresie przedstawiają tabele 2 i 3 . 
Tabela 2. Wielkość wymiany towarów przemysłowych Polski z krajami Grupy Wyszehradzkiej w okresie 2007-2014 (grupy SITC 3, 5-9, w mln EUR, ceny bieżące)

\begin{tabular}{|l|c|c|c|c|c|c|c|c|}
\hline \multicolumn{1}{|c|}{ Kraj } & 2007 & 2008 & 2009 & 2010 & 2011 & 2012 & 2013 & 2014 \\
\hline \multicolumn{10}{|c|}{ Wielkość polskiego importu } \\
\hline Czechy & 3689,3 & 4469,1 & 3357,5 & 4482,1 & 4976,2 & 4896,3 & 5064 & 5356,1 \\
\hline Słowacja & 1980,7 & 2414,4 & 1944,4 & 2475,5 & 2780,1 & 2758,5 & 2712,2 & 2731,3 \\
\hline Węgry & 2301,1 & 2261,6 & 1817,3 & 2101,6 & 2369,8 & 2184,8 & 2269,6 & 2360,5 \\
\hline \multicolumn{8}{|c|}{ Wielkość polskiego eksportu } \\
\hline Czechy & 4870 & 5706,6 & 3763,3 & 6187,2 & 7297,3 & 7705,8 & 8114,5 & 8379,5 \\
\hline Słowacja & 1900,5 & 2434,4 & 1853,6 & 2755,5 & 2820,7 & 3028,4 & 3248,1 & 3411,2 \\
\hline Węgry & 2567,7 & 2742 & 2203,5 & 2905,8 & 2996,2 & 2962,5 & 3394,6 & 3764,3 \\
\hline
\end{tabular}

Źródło: obliczenia własne na podstawie danych z: [Rocznik statystyczny... 2005-2015].

Tabela 3. Wielkość wymiany towarów przemysłowych między pozostałymi członkami Grupy Wyszehradzkiej w okresie 2007-2014 (grupy SITC 3, 5-9, w mln EUR, ceny bieżące)

\begin{tabular}{|l|c|c|c|c|c|c|c|c|}
\hline \multicolumn{1}{|c|}{ Kraje } & 2007 & 2008 & 2009 & 2010 & 2011 & 2012 & 2013 & 2014 \\
\hline \multicolumn{1}{|c|}{ Wielkość importu od partnera } \\
\hline Czechy-Słowacja & 4015,2 & 4683,2 & 3479,2 & 4353 & 5515 & 5822,8 & 5378,7 & 5373,6 \\
\hline Czechy-Węgry & 2247,2 & 2408,3 & 1507 & 1839,8 & 2130,4 & 2266,9 & 2301,7 & 2407,4 \\
\hline Węgry-Słowacja & 85,2 & 122,9 & 47,9 & 65,8 & 128,5 & 178,9 & 164,8 & 133,5 \\
\hline \multicolumn{10}{|c|}{ Wielkość eksportu do partnera } \\
\hline Czechy-Słowacja & 6654,8 & 7765,5 & 5915 & 7231,9 & 8874,8 & 9228,2 & 9020,9 & 9337,3 \\
\hline Czechy-Węgry & 2620,3 & 2574,1 & 1773 & 2092,4 & 2402,4 & 2521,6 & 2895,9 & 3356,5 \\
\hline Węgry-Słowacja & 65,1 & 69,7 & 83,8 & 136,8 & 308,4 & 358,3 & 516,1 & 518 \\
\hline
\end{tabular}

Źródło: dane Czech Statistical Office, https://www.czso.cz/csu/czso/home oraz Hungarian Central Statistical Office, https://www.ksh.hu (data dostępu: 20.09.2016).

W czasie kryzysu, oprócz 2009 r., obserwowano stały wzrost obrotów wymiany z każdym z krajów, co potwierdza wnioski z analizy danych z tabeli 1. Dominująca pozycja Polski wynika przede wszystkim z dużych rozmiarów naszego rynku w porównaniu z partnerami.

Spadek obrotów w 2009 r. dotyczył całego handlu unijnego, zarówno na rynku wewnętrznym, jak i zewnętrznym. Dotychczasowa tendencja poprawy struktury wymiany została zahamowana we wszystkich krajach Grupy Wyszehradzkiej, jednak w kolejnych latach proporcjonalnie do rozmiarów gospodarek powoli następował wzrost obrotów [Maciejewski 2014, s. 139].

$\mathrm{Z}$ analizy danych przedstawionych w tabelach 2 i 3 wynika, że utrzymane zostały tradycyjne kierunki wymiany z zachowaniem proporcji. Najbliżej ze sobą 
współpracują Czechy i Słowacja, natomiast wymiana poszczególnych państw z Węgrami jest odpowiednio mniejsza. Potwierdza to dość dużą spójność przede wszystkim kulturową.

\subsection{Wymiana handlowa Polska - Czechy}

Tak jak wszyscy członkowie Grupy Wyszehradzkiej Czechy należą do 80 najbardziej rozwiniętych gospodarek o dochodzie per capita powyżej 12700 USD (data.worldbank.org, 2016). Ich stopa wzrostu PKB od czasu wejścia do UE była dodatnia, z wyjątkiem lat 2009 i 2012. W 2014 r. sytuacja znów się poprawiła i wyniosła ona 1,9\% (http://euro-dane.com.pl/czechy, data dostępu: 25.04.2016), zaś w 2015 r. było to 4,3\% (http://www.bankier.pl/wiadomosc/CzechyPKB-rosnie-najszybciej-od-8-lat-7335627.html, data dostępu: 24.04.2016). Ten ostatni wzrost był największy od ośmiu lat. Podobna tendencja dotyczy spadku rozmiarów deficytu budżetowego i eksportu - od 2009 r. następuje stała poprawa.

Współpraca między Polską a Czechami zawsze była dość ożywiona, co świadczy o wysokiej spójności struktur handlowych. Nasz kraj należy do głównych odbiorców czeskich produktów - w 2015 r. byliśmy na trzecim miejscu, po Niemczech i Słowacji (http://www.praga.msz.gov.pl/pl/wspolpraca_dwustronna/wphi/, data dostępu: 22.04.2016) - i jest to tendencja stała. Według danych Czeskiego Urzędu Statystycznego czesko-polskie obroty handlowe w 2015 r. były o 8,3\% wyższe (r/r) i wyniosły 16 309,1 mln EUR. Wartość czeskiego eksportu do Polski wzrosła o 5,6\% i wyniosła 8327,5 mln EUR, a wartość importu z Polski o 10,7\% i wyniosła 9 981,6 mln EUR. Czeski deficyt w handlu z Polską wzrósł o 45,9\% i wyniósł 1 654,1 mln EUR [Dębiec 2016].

Czesi eksportują do Polski głównie maszyny i pojazdy drogowe, maszyny elektryczne, żeliwo i stal, a także wyroby przemysłowe. Podobnie przedstawia się struktura importu - są to w większości wyroby przemysłowe $(30,79 \%)$, w tym: żelazo i stal $(35,57 \%)$, maszyny i środki transportu $(25,62 \%)$, pojazdy samochodowe $(30,36 \%)$. Wielką popularnością cieszą się polskie meble (Forte) i odzież (Vistula, Ryłko, Tatuum) (http://www.exportgroup.pl/eksport/eksport-do-czech-eksport-na-slowacje.html, data dostępu: 20.04.2016).

\subsection{Wymiana handlowa Polska - Słowacja}

Słowacja to mały kraj, lecz z racji bliskości geograficznej i długotrwałych związków historycznych ważny partner handlowy Polski. Jej gospodarka rozwijała się podobnie jak czeska - po okresie dość wysokiego tempa wzrostu PKB po wejściu do UE (rekordowa wysokość w 2010 r. - 10,4\%), 2009 r. charakteryzował się tempem ujemnym $(-4,8 \%)$, na co mogły nałożyć się, oprócz kryzysu, skutki wprowadzenia euro (wzrost cen, zakupy w tańszej Polsce). Później znów nastąpił 
okres dodatniego, choć początkowo malejącego wzrostu (od 4,4\% w 2010 r. do 1,1\% w 2013 r. i 2,9\% w 2014 r.). Do czasu kryzysu kraj miał niewielki deficyt budżetowy (rekordowy był pod tym względem 2010 r.), jednak sytuacja powoli staje się korzystniejsza. Podobnie dzieje się w dziedzinie eksportu (http://euro-dane.com.pl/slowacja, data dostępu: 25.04.2016).

Według danych Słowackiego Urzędu Statystycznego w pierwszym kwartale 2015 r. polski eksport na Słowację wyniósł 706,16 mln EUR (szóste miejsce w słowackim imporcie). Polski import z tego kraju osiągnął wartość $1386,39 \mathrm{mln}$ EUR, co plasuje nasz kraj na trzecim miejscu w słowackim eksporcie. Słowacja w tym okresie odnotowała aktywne saldo obrotów handlowych z Polską w wysokości 680,23 mln EUR. W ogólnych obrotach słowackiego handlu zagranicznego w pierwszym kwartale $2015 \mathrm{r}$. nasz kraj zajmował trzecie miejsce (po Niemczech i Czechach) z wartością 2 092,55 mld EUR (http://www.bratyslawa.msz.gov.pl/pl/ wspolpraca_dwustronna/wspolpraca_gospodarcza/sytuacja_gospodarcza/gospodarka_slowacji_w_pierwszym_kwartale_2015_roku?channel=www, data dostępu: 25.04.2016).

Główne towary eksportowane przez Polskę to: wyroby przemysłu elektromaszynowego $27 \%$, w tym urządzenia mechaniczne i elektryczne $13,6 \%$, wyroby metalurgiczne $18,1 \%$, produkty chemiczne $14,8 \%$, mineralne $9 \%$, importuje się zaś głównie samochody i produkty elektroniczne. Z polskich towarów szczególnie chętnie są przez naszych partnerów kupowane części samochodowe (Saba), produkty Media-Tech oraz odzież (Reserved) (http://www.exportgroup.pl/eksport/ eksport-do-czech-eksport-na-slowacje.html, data dostępu: 20.04.2016).

\subsection{Wymiana handlowa Polska - Wegry}

Trzeci z członków Grupy Wyszehradzkiej, Węgry, jest mniej znaczącym partnerem handlowym Polski, znajdującym się na dwunastym miejscu w 2014 r. Rozwój gospodarczy przebiegał według podobnego schematu, jak w wyżej opisanych krajach. Od czasu wejścia do UE notowano stale wzrost gospodarczy, w 2009 r. spadek był bardzo głęboki $(-6,7 \%)$, ujemną wartość odnotowano też w 2012 i 2013 r. (-1,7\% i -0,1\%) (http://euro-dane.com.pl/wegry, data dostępu: 25.04.2016).

W 2014 r. Polska była szóstym partnerem handlowym Węgier (po Niemczech, Austrii, Rosji, Słowacji i Włoszech) oraz szóstym największym dostawcą towarów (między innymi po Niemczech, Austrii i Słowacji). Dane za 11 miesięcy 2015 r. udostępnione przez węgierski GUS wskazują Polskę jako czwartego największego eksportera na Węgry (po Niemczech, Austrii i Chinach) z eksportem na poziomie 4,2 mld EUR (wzrost o 12,1\%) oraz dodatnim saldem wymiany handlowej w wysokości 1 mld EUR. 
W polskim eksporcie dominują urządzenia mechaniczne i elektryczne, wyroby gumowe, tworzywa sztuczne oraz produkty chemii organicznej, wysoki udział mają także produkty przemysłu lekkiego oraz mineralne, import zaś z Węgier to głównie maszyny i urządzenia (ponad 30\%), przed pojazdami i wyrobami z metali nieszlachetnych, produktami chemicznymi i tworzywami sztucznymi [Janus 2016].

\section{Konkurencyjność polskiego eksportu artykułów przemysłowych do krajów Grupy Wyszehradzkiej}

Jak już wspomniano, wymiana między Polską a członkami Grupy jest dość ożywiona - są to ważni partnerzy, z którymi nasz kraj łączą długotrwałe związki. Nie znaczy to jednak, że nie jest możliwe zwiększenie tej współpracy i poprawa spójności ekonomicznej, gdyż zacieśnienie następuje na innych niż handlowa płaszczyznach.

W tabeli 4 pokazano wielkość udziałów polskiego eksportu poszczególnych grup towarowych do czterech państw Grupy Wyszehradzkiej. Dane zawarte w tabeli pozwalają stwierdzić, że w całym badanym okresie dominujące znaczenie w wymianie mają dwie grupy produktów - 6 i 7, czyli towary przemysłowe sklasyfikowane głównie według surowca oraz maszyny i urządzenia mające szczególne znaczenie jako produkty wysoko zaawansowane technologicznie, kluczowe dla poprawy konkurencyjności. Struktura wymiany nie podlegała gwałtownym zmianom. W przypadku Czech można zauważyć wyraźny wzrost udziału produktów grupy $7 \mathrm{w}$ ciągu ostatnich trzech lat, zwłaszcza samochodów i części zamiennych. W 2015 r. tendencja ta się utrzymała, co świadczy o utrwaleniu powiązań między krajami zwłaszcza przez współpracę w ramach firm (np. Zelmer).

Jeśli chodzi o Słowację, różnice udziałów obu tych grup w polskim eksporcie są znikome, chociaż istnieje niewielka przewaga produktów grupy 6 . W przypadku Węgier maszyny i urządzenia stanowią prawie połowę eksportu, choć po rekordowym 2010 r. udział ten aż do 2014 r. malał, wciąż jednak stanowił powyżej 40\% sprzedawanych towarów. Znaczenie zaś zyskiwały inne produkty przemysłowe.

Warto także odnotować spadek znaczenia paliw mineralnych (grupa 3), które aż do 2012 r. stanowiły znaczącą pozycję w handlu z naszymi sąsiadami. Świadczy to o zwiększeniu udziału towarów wyżej przetworzonych, a co się z tym wiąże - poprawie konkurencyjności polskiego handlu i jednocześnie reorientacji współpracy na poziom bardziej zaawansowany technicznie.

Same udziały w handlu nie dają pełnych podstaw do zbadania konkurencyjności polskiego eksportu. Konieczne jest uzupełnienie analizy przynajmniej o dwa najprostsze wskaźniki, których sposób interpretacji przedstawiono wyżej. Dopiero analiza wszystkich trzech rodzajów danych pozwala na (z konieczności 
uproszczone) wnioski dotyczące konkurencyjności polskiego eksportu wewnątrz Grupy Wyszehradzkiej.

Tabela 4. Procentowy udział eksportu poszczególnych grup towarowych SITC w całkowitym eksporcie Polski do danego kraju Grupy Wyszehradzkiej w latach 2007-2014

\begin{tabular}{|c|c|c|c|c|c|c|c|c|c|c|}
\hline \multirow{3}{*}{ Kraj } & \multicolumn{10}{|c|}{ Grupa SITC } \\
\hline & 3 & 5 & 6 & 7 & 8 & 3 & 5 & 6 & 7 & 8 \\
\hline & \multicolumn{5}{|c|}{2007} & \multicolumn{5}{|c|}{2008} \\
\hline Czechy & 13,07 & 8,8 & 26,19 & 24,88 & 13,38 & 11,92 & 9,06 & 25,12 & 26,17 & 13,79 \\
\hline Słowacja & 13,12 & 9,43 & 27,04 & 20,82 & 15,21 & 10,06 & 8,08 & 28,93 & 23,82 & 14,48 \\
\hline \multirow[t]{2}{*}{ Węgry } & 1,85 & 7,92 & 19,59 & 46,96 & 10,43 & 2,34 & 7,9 & 19,35 & 44,72 & 10,58 \\
\hline & \multicolumn{5}{|c|}{2009} & \multicolumn{5}{|c|}{2010} \\
\hline Czechy & 11,65 & 8,23 & 21,28 & 29,53 & 14 & 11,09 & 9,32 & 26,6 & 26,6 & 12,28 \\
\hline Słowacja & 10,23 & 7,97 & 28,56 & 21,43 & 14,4 & 10,23 & 6,71 & 30,23 & 26,48 & 11 \\
\hline \multirow[t]{2}{*}{ Węgry } & 1,49 & 8,77 & 17,33 & 45,78 & 9,63 & 1,94 & 7,64 & 17,92 & 49,84 & 8,03 \\
\hline & \multicolumn{5}{|c|}{2011} & \multicolumn{5}{|c|}{2012} \\
\hline Czechy & 12,43 & 9,76 & 27,71 & 24,32 & 11,29 & 11,12 & 9,35 & 27,69 & 26,25 & 10,53 \\
\hline Słowacja & 13,38 & 8,56 & 26,41 & 23,24 & 12,44 & 8,05 & 8,31 & 26,31 & 25,28 & 13,27 \\
\hline \multirow[t]{2}{*}{ Węgry } & 1,89 & 9,4 & 21,27 & 44,4 & 8,6 & 2,19 & 10,13 & 22,72 & 41,77 & 8,59 \\
\hline & \multicolumn{5}{|c|}{2013} & \multicolumn{5}{|c|}{2014} \\
\hline Czechy & 9,6 & 9,66 & 25,72 & 28,45 & 11,05 & 9,95 & 9,33 & 23,39 & 31,16 & 11,2 \\
\hline Słowacja & 7,27 & 9,22 & 24,95 & 24,97 & 12,99 & 6,49 & 10,3 & 25,46 & 24,2 & 14,7 \\
\hline Węgry & 2,34 & 10,44 & 23,1 & 40,64 & 9,46 & 1,37 & 9,58 & 21,63 & 43,34 & 10,4 \\
\hline
\end{tabular}

Objaśnienia: grupa 3 - paliwa mineralne, grupa 5 - wyroby chemiczne, grupa 6 - towary przemysłowe, grupa 7 - maszyny i urządzenia, grupa 8 - różne wyroby przemysłowe. $Z$ uwagi na częsty brak lub znikomy udział w wymianie pominięto produkty z grupy 9 (pozostałe towary nieuwzględnione w klasyfikacji).

Źródło: obliczenia własne na podstawie danych z: [Rocznik statystyczny... 2005-2015].

W tabeli 5 przedstawione zostały wartości wskaźnika RCA użytego do zbadania wysokości przewag względnych polskiego eksportu w analizowanych grupach towarowych. Im większe odchylenie od zera, tym jednocześnie spójność ekonomiczna w danej dziedzinie jest mniejsza.

Jak wynika z tabeli 5, w badanym okresie w handlu z Czechami Polska wykazywała stałą, choć niewielką przewagę względną w wymianie towarów z grup 3 i 7, zatem raczej kontrastowych, co oznacza dość wysoką spójność w tych dziedzinach. Towary z grupy 5, czyli wyroby chemiczne, okazały się dosyć wrażliwe na zmiany kryzysowe, bo choć utrata przewagi nie była zbyt duża, to jednak utrzymywała się przez trzy kolejne lata. Jest to zrozumiałe, gdyż Czechy mają silnie 
rozwinięty przemysł chemiczny, szczególnie farmaceutyczny, więc rywalizacja jest silna. Pomyślnym symptomem jest występowanie stałej przewagi w przypadku grupy 7. Chociaż jest ona znikoma, nie zniknęła nawet w okresie największego nasilenia kryzysu i po osiągnięciu najniższego poziomu w 2011 r. (niecałe $0,1)$ wzrosła znacząco w roku kolejnym i wprawdzie nieznacznie, ale nadal rośnie, co świadczy o poprawie polskiej konkurencyjności.

W przypadku Słowacji na początku badanego okresu przewagę względną niemal w każdej dziedzinie wykazywali nasi partnerzy. Stałym wyjątkiem są różne towary przemysłowe. Rozmiar tej przewagi praktycznie nie ulega zmianom. $\mathrm{Z}$ upływem lat sytuacja ogólna zmieniała się na korzyść Polski, ale podlega dość dużym wahaniom. Wprowadzenie euro, jak się wydaje, nie miało w tym względzie żadnego znaczenia. Przewaga w grupie 7, dość ważnej także ze względu na rozmiary eksportu, pojawiła się dopiero w 2012 r. i jest nieznaczna.

Tabela 5. Wskaźniki RCA dla badanych grup towarowych polskiego eksportu do krajów Grupy Wyszehradzkiej w latach 2007-2014

\begin{tabular}{|c|c|c|c|c|c|c|c|c|c|c|}
\hline \multirow{3}{*}{ Kraj } & \multicolumn{10}{|c|}{ Grupa SITC } \\
\hline & 3 & 5 & 6 & 7 & 8 & 3 & 5 & 6 & 7 & 8 \\
\hline & \multicolumn{5}{|c|}{2007} & \multicolumn{5}{|c|}{2008} \\
\hline Czechy & 1,01 & $-0,02$ & 0,15 & 0,06 & 0,88 & 0,46 & $-0,08$ & 0,16 & 0,13 & 0,9 \\
\hline Słowacja & $-0,03$ & $-0,08$ & $-0,32$ & $-0,15$ & 1,36 & $-0,22$ & $-0,1$ & $-0,15$ & $-0,05$ & 1,29 \\
\hline \multirow[t]{2}{*}{ Węgry } & 0,63 & $-0,63$ & 0,19 & 0,13 & 0,84 & $-0,002$ & $-0,63$ & 0,35 & 0,24 & 0,98 \\
\hline & \multicolumn{5}{|c|}{2009} & \multicolumn{5}{|c|}{2010} \\
\hline Czechy & 1,03 & $-0,08$ & $-2,13$ & 0,25 & 1,15 & 0,6 & $-0,07$ & 0,33 & 0,14 & 1,15 \\
\hline Słowacja & 0,05 & $-0,03$ & $-0,13$ & $-0,39$ & 1,19 & 0,14 & $-0,13$ & 0,07 & $-0,06$ & 1,26 \\
\hline \multirow[t]{2}{*}{ Węgry } & 0,25 & $-0,46$ & 0,35 & 0,23 & 0,74 & 0,33 & $-0,62$ & 0,46 & 0,47 & 0,79 \\
\hline & \multicolumn{5}{|c|}{2011} & \multicolumn{5}{|c|}{2012} \\
\hline Czechy & 0,79 & 0,08 & 0,43 & 0,09 & $-0,09$ & 1,16 & 0,11 & 0,47 & 0,3 & 1,14 \\
\hline Słowacja & 0,01 & $-0,11$ & $-0,18$ & $-0,05$ & 0,05 & $-0,23$ & 0,18 & $-0,08$ & 0,03 & 1,19 \\
\hline \multirow[t]{2}{*}{ Węgry } & 0,12 & $-0,6$ & 0,49 & 0,36 & $-0,36$ & 0,57 & $-0,49$ & 0,58 & 0,4 & 0,65 \\
\hline & \multicolumn{5}{|c|}{2013} & \multicolumn{5}{|c|}{2014} \\
\hline Czechy & 1,09 & 0,14 & 0,5 & 0,38 & 1,06 & 1,09 & 0,14 & 0,5 & 0,37 & 1,06 \\
\hline Słowacja & $-0,21$ & 0,33 & 0,08 & 0,07 & 1,14 & $-0,21$ & 0,33 & 0,08 & 0,06 & 1,14 \\
\hline Węgry & 0,59 & $-0,43$ & 0,73 & 0,5 & 0,76 & 0,59 & $-0,43$ & 0,73 & 0,5 & 0,76 \\
\hline
\end{tabular}

Objaśnienia: jak do tabeli 4.

Źródło: obliczenia własne na podstawie danych z: [Rocznik statystyczny... 2005-2015].

Jeśli chodzi o Węgry, trwały brak przewagi dotyczy grupy 5, czyli chemikaliów stanowiących dość znaczącą pozycję w polskim eksporcie. Stale podnosi się 
niewielka przewaga grupy 7 stanowiącej przeważającą część węgierskiego importu z Polski. Warto też zauważyć powolny wzrost wartości wskaźnika w przypadku sprzedaży towarów z grupy 6 będących drugą co do wielkości dziedziną polskiego eksportu do Węgier.

$\mathrm{Z}$ uwagi na niewielkie znaczenie handlowe i nieregularność wymiany analiza produktów z grupy „towary gdzie indziej niesklasyfikowane” nie została przeprowadzona.

Uzupełnienie stanowi analiza wskaźników IIT, stanowiących miernik podobieństwa struktur gospodarczych, przedstawiona w tabeli 6. Im bardziej wartość wskaźnika zbliża się do 100 , tym podobieństwo struktur wymiany jest większe.

Tabela 6. Wskaźniki IIT dla grup 3, 5-8 SITC dla lat 2007-2014 (w \%)

\begin{tabular}{|c|c|c|c|c|c|c|c|c|c|c|}
\hline \multirow{3}{*}{ Kraj } & \multicolumn{10}{|c|}{ Grupa SITC } \\
\hline & 3 & 5 & 6 & 7 & 8 & 3 & 5 & 6 & 7 & 8 \\
\hline & \multicolumn{5}{|c|}{2007} & \multicolumn{5}{|c|}{2008} \\
\hline Czechy & 53,28 & 99,19 & 92,64 & 97,23 & 58,68 & 77,39 & 96 & 91,87 & 93,77 & 57,86 \\
\hline Słowacja & 98,57 & 95,76 & 84,23 & 92,45 & 40,76 & 88,88 & 95,18 & 92,31 & 97,41 & 43,05 \\
\hline \multirow[t]{2}{*}{ Węgry } & 69,37 & 69,5 & 90,44 & 93,51 & 60,18 & 99,9 & 69,72 & 82,73 & 88,23 & 54,48 \\
\hline & \multicolumn{5}{|c|}{2009} & \multicolumn{5}{|c|}{2010} \\
\hline Czechy & 52,69 & 95,88 & 21,32 & 87,69 & 48,2 & 70,72 & 96,71 & 83,66 & 93,17 & 48,04 \\
\hline Słowacja & 97,35 & 98,42 & 93,44 & 80,57 & 46,64 & 93,18 & 93,77 & 96,62 & 96,98 & 44,37 \\
\hline \multirow[t]{2}{*}{ Węgry } & 87,46 & 77,3 & 82,48 & 88,81 & 64,84 & 83,7 & 69,99 & 77,22 & 77,03 & 62,52 \\
\hline & \multicolumn{5}{|c|}{2011} & \multicolumn{5}{|c|}{2012} \\
\hline Czechy & 62,36 & 95,95 & 78,87 & 95,3 & 47,35 & 47,86 & 94,5 & 77,06 & 85,24 & 48,35 \\
\hline Słowacja & 99,34 & 94,44 & 90,85 & 97,34 & 46,87 & 88,66 & 91,09 & 96,14 & 98,5 & 46,5 \\
\hline \multirow[t]{2}{*}{ Węgry } & 94,16 & 70,75 & 76,02 & 82,23 & 71,46 & 72,05 & 76,17 & 72,02 & 80,3 & 68,48 \\
\hline & \multicolumn{5}{|c|}{2013} & \multicolumn{5}{|c|}{2014} \\
\hline Czechy & 50,47 & 92,92 & 75,68 & 81,61 & 51,62 & 43,88 & 91,83 & 11,72 & 76,37 & 55,75 \\
\hline Słowacja & 89,47 & 83,86 & 96,18 & 96,71 & 48,61 & 90,46 & 79,75 & 96,34 & 99,86 & 50,73 \\
\hline Węgry & 71,39 & 78,84 & 65,08 & 75,33 & 63,95 & 99,62 & 73,84 & 64,68 & 64,82 & 67,14 \\
\hline
\end{tabular}

Objaśnienia: jak do tabeli 4.

Źródło: obliczenia własne na podstawie danych z: [Rocznik statystyczny... 2005-2015].

Z tabeli 6 wynika, że podobieństwo struktur w wymianie, a co za tym idzie spójność ekonomiczna, choć wysokie w każdej z grup, podlega jednak znacznym wahaniom w badanym okresie. W przypadku Czech najwyższe wartości od lat są notowane w grupie 5, choć od 2011 r. notuje się regularny spadek - Polska zaczyna powiększać swą przewagę konkurencyjną, chociaż ma ona niewielki wpływ na poprawę konkurencyjności ogólnej z uwagi na niewielki udział w całko- 
witym eksporcie (niecałe 10\%). Dość znaczne wahania dotyczą największej pod względem wartości sprzedaży grupy 7 , lecz choć podobieństwo struktur jest dość wysokie, trudno zauważyć jakiś regularny trend. Niepokojące jest jednoczesne zwiększenie wpływów z eksportu i spadek wartości wskaźnika w ostatnim badanym roku, może to jednak być wynikiem zwiększonej sprzedaży części zamiennych, a nie gotowych wyrobów. Aby dokładniej wyjaśnić przyczyny, konieczna jest pogłębiona analiza przy większej dezagregacji danych. Sytuacja wygląda podobnie w odniesieniu do grupy 6 .

W przypadku Słowacji najmniej podobne są struktury wymiany produktów z grupy 8 (różne wyroby przemysłowe), tam też w całym badanym okresie występuje przewaga względna. W pozostałych przypadkach podobieństwo jest dość wysokie, choć ulega zmianom. Ważny jest spadek udziału w wymianie produktów z grupy 3 (paliwa) jako najmniej przetworzonych na rzecz grup 6 i 7, w których nastąpiła też poprawa wartości pozostałych wskaźników, co oznacza, że konkurencyjność Polski w tej wymianie powoli rośnie.

Ogólne podobieństwo struktur wymiany z Węgrami jest mniejsze niż dla dwóch wyżej analizowanych krajów, choć również dość wysokie. Wartości wskaźnika IIT ulegają większym i bardziej nieregularnym zmianom niż w pozostałych przypadkach. Może to być wynikiem mniej rozwiniętych kontaktów handlowych w badanym obszarze, bo choć Węgry są dwunastym co do wielkości partnerem Polski w wymianie wewnątrz UE, to jednak jej wartość to niecałe $3 \%$ udziału w imporcie i niewiele ponad 3\% w eksporcie. Świadczy to o dość niskim stopniu spójności obu gospodarek. Największe podobieństwo struktur dotyczy najczęściej grupy 3, czyli towarów bardzo nisko przetworzonych, lecz ich udział w całym eksporcie waha się między 1,5-2,5\%, zatem nie może być wyznacznikiem konkurencyjności. Dość regularnie spada jednak podobieństwo struktur w grupie 6 będącej drugą co do wartości eksportu. Widoczny jest systematyczny wzrost przewagi względnej, wciąż jednak jest ona niewielka. Silnie zmienia się wartość wskaźnika IIT w grupie 7 stanowiącej największy odsetek eksportu. Zmiany te nie do końca są związane z kryzysem gospodarczym, bo choć widoczne są zależności pomiędzy spadkiem tempa wzrostu PKB a obniżeniem wskaźnika IIT, to jednak przypuszczalnie czynnikiem wpływającym silniej na spadek podobieństwa jest prowadzona przez Węgry polityka gospodarcza. Polska w przypadku większości grup wykazuje przewagę względną, co oznacza poprawę konkurencyjności naszego eksportu i pozytywny kierunek rozwoju przemysłu, choć w stosunku do wyżej rozwiniętych gospodarek UE wciąż jeszcze nie zostały osiągnięte zadowalające wyniki. Pogorszenie sytuacji Węgier powoduje też pewną destabilizację całej Grupy Wyszehradzkiej, często postrzeganej przez zagranicznych partnerów jako silniej powiązanej gospodarczo i politycznie niż ma to miejsce w rzeczywistości. 
Tabela 7 zawiera podsumowanie wyników badania konkurencyjności dla wszystkich omawianych grup SITC.

Tabela 7. Zbiorcze wartości wskaźników IIT (w \%) i RCA dla grup 3, 5-9 SITC w latach 2007-2014 w porównaniu z wybranymi krajami i grupami Unii Europejskiej

\begin{tabular}{|l|c|c|c|c|c|c|c|c|}
\hline \multirow{2}{*}{ Wyszczególnienie } & RCA & IIT & RCA & IIT & RCA & IIT & RCA & IIT \\
\cline { 2 - 11 } & \multicolumn{2}{|c|}{2007} & \multicolumn{2}{|c|}{2008} & \multicolumn{2}{c|}{2009} & \multicolumn{2}{c|}{2010} \\
\hline Czechy & 0,28 & 86,21 & 0,24 & 87,84 & 0,24 & 94,3 & 0,32 & 84,02 \\
\hline Słowacja & $-0,04$ & 97,93 & 0,01 & 99,59 & 0,01 & 97,61 & 0,11 & 94,65 \\
\hline Węgry & 0,11 & 94,52 & 0,19 & 90,4 & 0,19 & 90,39 & 0,32 & 83,94 \\
\hline Grupa Wyszehradzka & 0,16 & 92,1 & 0,17 & 91,32 & 0,09 & 95,31 & 0,27 & 86,66 \\
\hline UE-15 & $-0,07$ & 96,71 & $-0,07$ & 96,73 & 0,1 & 94,9 & 0,13 & 93,78 \\
\hline UE-28 & $-0,01$ & 99,88 & $-0,0001$ & 99,99 & 0,12 & 93,89 & 0,16 & 92,01 \\
\hline & \multicolumn{2}{|c|}{2011} & \multicolumn{2}{|c|}{2012} & \multicolumn{2}{|c|}{2013} & \multicolumn{2}{|c|}{2014} \\
\hline Czechy & 0,38 & 81,09 & 0,45 & 77,71 & 0,47 & 76,85 & 0,47 & 96,77 \\
\hline Słowacja & 0,02 & 99,28 & 0,09 & 95,34 & 0,18 & 91,01 & 0,18 & 83,54 \\
\hline Węgry & 0,24 & 88,33 & 0,31 & 84,89 & 0,4 & 80,14 & 0,4 & 52,09 \\
\hline Grupa Wyszehradzka & 0,26 & 87,14 & 0,33 & 83,61 & 0,39 & 81,01 & 0,4 & 57,45 \\
\hline UE-15 & 0,1 & 95,27 & 0,18 & 94,15 & 0,13 & 93,4 & 0,15 & 92,78 \\
\hline UE-28 & 0,14 & 92,99 & 0,19 & 90,35 & 0,2 & 90,15 & 0,24 & 88,29 \\
\hline
\end{tabular}

Źródło: obliczenia własne na podstawie danych z: [Rocznik statystyczny... 2005-2015].

Okres kryzysu powiększył przewagę konkurencyjną Polski wobec państw z Grupy Wyszehradzkiej, co potwierdzają także dane makroekonomiczne. Największe podobieństwo struktur oraz spójność przed kryzysem i w jego trakcie wykazuje wymiana pomiędzy Polską a Słowacją. Sytuacja ta uległa zmianie w ostatnich latach - na plan pierwszy wysunęły się Czechy, co oznacza, że nasz kraj powoli poprawia swoją pozycję na arenie unijnej, gdyż nasz sąsiad stara się zdecydowanie przyspieszyć rozwój, a zatem podobieństwo struktur połączone z wysokim udziałem we wzajemnym handlu sprzyja również rozwojowi Polski. Analiza potwierdza także wciąż istniejące oddalenie Węgier od głównego nurtu polskiego handlu. Wydaje się, że współpraca w ramach Grupy Wyszehradzkiej nie wpłynęła na dokonanie znaczącego przełomu w stosunkach gospodarczych i wymiana pozostała na zbliżonym poziomie przez cały badany okres. Podobnie jest ze spójnością ekonomiczną w dziedzinie handlu artykułami przemysłowymi.

Zbiorcze wskaźniki wykazują coraz większe różnice struktur wymiany między Polską a Grupą Wyszehradzką, powiększa się natomiast przewaga względna, co jest wynikiem zwiększenia eksportu wyrobów z najbardziej zaawansowanych technologicznie grup SITC. 
Przytoczone dla porównania wskaźniki dla „starej” Unii wykazują osłabienie konkurencyjności polskiego eksportu, co jest wciąż jeszcze skutkiem kryzysu. Mimo zwiększenia wartości wymiany w ujęciu nominalnym załamanie gospodarcze spowolniło rozwój we wszystkich krajach. Wobec UE-15 spadek ten jest powolny i stosunkowo łatwy do zahamowania, co potwierdza względną stabilność polskiej gospodarki. Na pogorszenie wskaźników dla całej UE wpływa słabsza pozycja krajów przyjętych później (pominiętych w analizie) i ich większa podatność na kryzysy.

\section{Konkurencyjność wymiany handlowej między pozostałymi członkami Grupy Wyszehradzkiej a spójność gospodarcza}

Analiza konkurencyjności wymiany produktów przemysłowych między poszczególnymi krajami jest jednym ze sposobów na ukazanie także stopnia spójności gospodarczej między nimi. Jak już wspomniano, największe wartości przyjmuje handel między gospodarkami podobnymi pod względem kultury, poziomu rozwoju gospodarczego, historii. Analiza handlu światowego pozwala stwierdzić, że największe nasilenie wymiany dotyczy głównie krajów sąsiadujących, mających długotrwałe związki historyczne podobny stopień rozwoju, a także dotyczy często dóbr substytucyjnych. Na przykład w wymianie między Polską a Niemcami dominującą grupą towarową, zarówno w eksporcie, jak i imporcie, są maszyny i urządzenia i ta tendencja od dawna się nie zmienia. W odniesieniu do krajów Grupy Wyszehradzkiej sytuacja kształtuje się podobnie, co wykazuje analiza danych z tabeli 8 .

Tabela 8. Zbiorcze wartości wskaźników RCA i IIT (w \%) dla grup SITC 3, 5-9 w latach 2007-2014

\begin{tabular}{|l|c|c|c|c|c|c|c|c|}
\hline \multirow{2}{*}{ Kraje } & RCA & IIT & RCA & IIT & RCA & IIT & RCA & IIT \\
\cline { 2 - 10 } & \multicolumn{2}{|c|}{2007} & \multicolumn{2}{c|}{2008} & \multicolumn{2}{c|}{2009} & \multicolumn{2}{c|}{2010} \\
\hline Czechy-Słowacja & 0,51 & 75,26 & 0,51 & 75,24 & 0,53 & 74,07 & 0,51 & 75,15 \\
\hline Czechy-Węgry & 0,15 & 92,34 & 0,07 & 96,67 & 0,16 & 91,89 & 0,13 & 93,58 \\
\hline Węgry-Słowacja & 0,15 & 86,63 & $-0,57$ & 72,38 & $-0,56$ & 72,74 & 0,73 & 64,96 \\
\hline & \multicolumn{3}{|c|}{2011} & \multicolumn{2}{c|}{2012} & \multicolumn{2}{c|}{2013} & \multicolumn{2}{c|}{2014} \\
\hline Czechy-Słowacja & 0,48 & 76,65 & 0,46 & 77,37 & 0,52 & 74,71 & 0,55 & 73,06 \\
\hline Czechy-Węgry & 0,12 & 94 & 0,11 & 94,68 & 0,23 & 88,57 & 0,33 & 83,53 \\
\hline Węgry-Słowacja & 0,88 & 58,82 & $-0,48$ & 76,46 & 1,15 & 48,41 & 1,36 & 40,98 \\
\hline
\end{tabular}

Źródło: obliczenia własne na podstawie danych Czech Statistical Office, https://www.czso.cz/csu/ czso/home oraz Hungarian Central Statistical Office, https://www.ksh.hu (data dostępu: 20.09.2016). 
Wysokie wartości wskaźnika IIT w badanym okresie w wymianie czesko-węgierskiej potwierdzają tezę o wysokim stopniu spójności obu gospodarek w ramach wymiany. Był to tradycyjny kierunek handlu tych państw. Potwierdza to także niska wartość wskaźników przewagi względnej. Jeśli zaś chodzi o handel czesko-słowacki, to chociaż wartość obrotów jest duża, jednak stopień spójności mniejszy niż w handlu z Węgrami. Czechy mają niewielką, lecz trwałą przewagę względną nad partnerem, która prawie się nie zmienia. Może to być wynikiem nawiązania przez oba kraje szerszej współpracy z większymi partnerami, takimi jak Polska czy kraje „starej” UE, co przekłada się na brak zainteresowania rozwojem handlu z najbliższym, lecz niewielkim sąsiadem.

Trudno stwierdzić na podstawie dostępnych źródeł, co wpłynęło na pojawienie się dość dużej przewagi względnej w przypadku wymiany Węgier ze Słowacją w ostatnich latach. Stopień podobieństwa struktur handlowych obu krajów również ulegał w tym czasie dużym wahaniom, wyraźnie się zmniejszając w dwóch ostatnich latach mimo znaczącego zwiększenia wartości wymiany. Może to być skutkiem zmian w polityce wewnętrznej Węgier, nastawionej proimportowo, tym bardziej że podobna tendencja jest zauważalna w odniesieniu do pozostałych członków Grupy.

\section{Wnioski}

Powyższa analiza pozwala na wysnucie kilku wniosków. Przede wszystkim Polska powinna rozwijać eksport do Czech i na Słowację. Do zalet należy zaliczyć to, że oba kraje są bezpośrednimi sąsiadami Polski, wymiana z nimi kształtuje się na dość wysokim poziomie, a spójność ekonomiczna, zwłaszcza w przypadku Czech, jest relatywnie wysoka w porównaniu z innymi członkami Grupy Wyszehradzkiej, co daje Polsce duże szanse dalszego rozwoju. Należy też zwrócić uwagę, że walutą Słowacji jest euro, co może sprzyjać zwiększeniu polskiego eksportu, częściowo ze względu na niższe ceny naszych wyrobów. Nie jest to jednak pewne rozwiązanie - Czechy również nie należą do strefy euro, a Słowację łączą z nimi znacznie bliższe związki wynikające choćby z zaszłości historycznych, jednak Polska wykazuje dużo większą spójność gospodarczą, mierzoną podobieństwem struktur, ze Słowacją, co dobrze rokuje na przyszłość. Pewną dodatkową możliwość rozwoju stwarzają rozwiązania niekonwencjonalne. Słowacja to jeden z najczęściej odwiedzanych przez Polaków krajów, co sprzyja nawiązywaniu szerszych kontaktów, także handlowych, o czym można się przekonać, analizując polski eksport żywności.

Pewne zaniepokojenie może budzić sytuacja wymiany polsko-węgierskiej. Choć udział tego kraju w polskim handlu nie jest zbyt duży, jednak Węgry jako 
członek Grupy Wyszehradzkiej stanowią dość ważny element naszej działalności na forum unijnym. Osłabienie tamtejszej gospodarki daje wprawdzie Polsce pewną przewagę, jednak dla rozwoju konkurencyjności najważniejsza jest duża i stabilna wymiana z krajami wysoko rozwiniętymi, o podobnych strukturach wymiany. Co istotne, Węgry mają niewiele mniejszą populację niż Czechy, zatem możliwości absorpcyjne polskich wyrobów, tańszych i często lepszej jakości niż zachodnich, również są dosyć duże, zatem taki rozwój handlu jest możliwy pod warunkiem zwiększenia tempa wzrostu PKB partnera. Rozszerzenie analizy o pozostałe kraje Grupy Wyszehradzkiej pokazuje jednak, że nie jest to sytuacja wyjątkowa, a Węgry szukają partnerów raczej poza badanym ugrupowaniem.

Zauważyć można wysokie podobieństwo struktur wymiany z członkami Grupy Wyszehradzkiej utrzymujące się przez cały badany okres. Jest to dowodem na podobną ścieżkę rozwoju wszystkich państw Grupy Wyszehradzkiej i istniejącą spójność gospodarczą, choć nie jest ona najwyższa. Polska nie wykazuje znaczącej przewagi konkurencyjnej w handlu, co jednak nie znaczy, że poprawa sytuacji nie jest możliwa, przeciwnie, rosnący udział w wymianie naszych sąsiadów i utrzymujący się udział Węgier świadczą o coraz większej współpracy i zbieżności kierunków rozwoju. Na pewno nie sprzyja jej skupianie się wyłącznie na poprawie konkurencji kosztowej poprzez przenoszenie produkcji (w całości lub części) do krajów sąsiednich (co jednak świadczy o poprawie spójności), tym bardziej że często wiąże się to z dużym spadkiem jakości, a co za tym idzie - również zaufania do firmy (klasycznym przykładem są produkty Zelmera) i tym samym konkurencyjności całej gospodarki (z uwagi na znaczenie tej grupy towarowej w eksporcie). Większa zatem spójność ekonomiczna w ramach Grupy Wyszehradzkiej niekoniecznie musi być korzystna dla rozwoju gospodarczego Polski.

Obserwowane wartości wskaźników, zwłaszcza IIT, potwierdzają postawioną wcześniej tezę o znacznym podobieństwie struktur handlu, a co się z tym wiąże - spójności gospodarczej badanych krajów. Jej poziom zmienia się dość wolno i wciąż utrzymuje się w tradycyjnych ramach - partnerzy niechętnie zmieniają kierunki handlu, choć wciąż rosnący wolumen wymiany jest dobrym prognostykiem. Pojawia się jednak pytanie, czy ten kierunek rozwoju, w świetle wyżej sformułowanego wniosku, jest właściwy.

Warto zauważyć, że wszystkie analizowane kraje mają dość podobne podstawy konkurencyjności, wobec czego należałoby rozważyć możliwość wymiany doświadczeń pozwalających na poprawę ich rozwoju [Daszkiewicz i Olczyk 2014, s. 47-48] i dalszy wzrost konkurencyjności. Jest to możliwe dzięki utworzeniu odpowiedniego forum współpracy oraz pewną specjalizację w produkcji określonych towarów, a także szerszą kooperację przez zawieranie porozumień w ramach regionu. 
Trzeba też zwrócić uwagę, że za rosnącą wymianą handlową nie nadąża rozwój infrastruktury transportowej, stanowiąc istotną barierę także dla spójności. Konieczne jest przede wszystkim wyeliminowanie tak zwanych wąskich gardeł na granicach uniemożliwiających pełne wykorzystanie potencjału współpracy gospodarczej [Sadecki 2013, s. 103].

Należy jednak pamiętać, że samo istnienie Grupy Wyszehradzkiej ze względu na warunki handlu zagranicznego nie ma znaczenia, gdyż wszelkie wymiany odbywają się według zasad obowiązujących w UE.

\section{Literatura}

Brodzicki T. [2013], Potencjał konkurencyjny państw Grupy Wyszehradzkiej - zmiany strukturalne w wymianie handlowej [w:] Konkurencyjność międzynarodowa i regionalna państw Grupy Wyszehradzkiej: Polski, Wegier, Czech i Słowacji, red. A. Zielińska-Głębocka, K. Gawlikowska-Hueckel, Wydawnictwo Uniwersytetu Gdańskiego, Gdańsk.

Daszkiewicz N., Olczyk M. [2008], Konkurencyjność podmiotów - ujęcie teoretyczne [w:] Konkurencyjność. Poziom makro, mezo i mikro, red. N. Daszkiewicz, PWN, Warszawa.

Daszkiewicz N., Olczyk M. [2014], Competitiveness of the Visegrad Countries - Paths for Competitiveness Growth [w:] International Competitiveness in Visegrad Countries: Macro and Micro Perspectives, red. D. Kiendl-Wender, K. Wach, F.H. Joanneum, Graz.

Dębiec K. [2016], Polsko-czeska wymiana handlowy w 2015 r., https://czechrepublic.trade. gov.pl/pl/wymiana-handlowa/181176,polsko-czeska-wymiana-handlowa-w-2015-r-html (data dostępu: 20.04.2016).

Flejterski S. [1984], Istota i mierzenie konkurencyjności międzynarodowej, „Gospodarka Planowa", nr 9.

Gorynia M., Łaźniewska E. [2010], Kompendium wiedzy o konkurencyjności, PWN, Warszawa.

Hübner D. [1993], Międzynarodowa konkurencyjność gospodarki a strategia rozwoju, „Ekonomista”, $\mathrm{nr} 4$.

Jagiełło E.M. [2008], Strategiczne budowanie konkurencyjności gospodarki, Wydawnictwo „Poltext”, Warszawa.

Janus E. [2016], Wymiana handlowa z Węgrami, https://hungary.trade.gov.pl/pl/aktualnosci/184884,wymiana-handlowa-z-wegrami.html (data dostępu: 20.04.2016).

Maciejewski M. [2014], Rola czynników wytwórczych w eksporcie państw Grupy Wyszehradzkiej na rynki pozaunijne [w:] Tradycyjne i nowe kierunki rozwoju handlu międzynarodowego, red. S. Wydymus, M. Maciejewski, CeDeWu, Warszawa.

Misala J. [2011], Międzynarodowa konkurencyjność gospodarki narodowej, PWE, Warszawa.

Ocena korzyści uzyskiwanych przez państwa UE-15 w wyniku realizacji polityki spójności w krajach Grupy Wyszehradzkiej. Raport końcowy [2011], Instytut Badań Strukturalnych, Warszawa.

Puślecki Z., Walkowski M. [2010], Polityka wzrostu konkurencyjności Unii Europejskiej wobec USA i Japonii, Dom Wydawniczy Elipsa, Warszawa. 
Radło M.J. [2008], Międzynarodowa konkurencyjność gospodarki. Uwagi na temat definicji, czynników i miar [w:] Czynniki i miary międzynarodowej konkurencyjności gospodarek w kontekście globalizacji - wstępne wyniki badań, red. W. Bieńkowski i in., Prace i Materiały Nr 284, Instytut Gospodarki Światowej, SGH, Warszawa.

Rocznik statystyczny handlu zagranicznego, GUS, Warszawa, lata 2005-2015.

Sadecki A. [2013], Grupa Wyszehradzka - środkowoeuropejski przykład współpracy regionalnej [w:] Grupa Wyszehradzka - Chorwacja: źródła jedności i perspektywy rozwoju, red. A. Gil, „Rocznik Instytutu Europy Środkowo-Wschodniej”, r. 11, z. 1.

Szymanik E. [2016], Konkurencyjność przedsiębiorstwa - główne aspekty, „Zeszyty Naukowe Uniwersytetu Ekonomicznego w Krakowie”, nr 5(953), https://doi.org/ 10.15678/ZNUEK.2016.0953.0507.

Szymanik E. [2017], Konkurencyjność eksportu - nowe czynniki, „Przegląd Zachodni”, nr 2 (w druku).

Wierzbołowski J. [1995], Państwo jako aktywny uczestnik kształtowania międzynarodowej konkurencyjności [w:] Międzynarodowa konkurencyjność gospodarki Polski - uwarunkowania i perspektywy, red. M. Lubiński, T. Smuga, Raporty. Studia nad Konkurencyjnością, nr 35, IRiSS, Warszawa.

\section{The Competitiveness of Polish Industrial Goods Exports to the Visegrad Group Countries and the Economic Coherence of the Group}

(Abstract)

The article examines the competitiveness of the export of Polish industrial goods to the countries of the Visegrad Group. Competitiveness was analysed using the main indicators RCA, IIT and export shares. Given the possibility for expanded trade within the group, this issue is important. The research was done to show the opportunity which the coherence of export presents. The conclusions confirm that there are indeed opportunities, but infrastructural barriers must be overcome and an effort must be made to exchange experience gained from improving competitiveness. These measures could boost competitiveness for all because every member of the Group had the same initial terms, but their different approaches to development have yielded different economic results.

Keywords: Visegrad Group, export competitiveness, economies' coherence, European Union. 